cannot be great. This is because surface sea waters have caught and have failed to dissipate downward such large amounts of fall-out that the concentration of cæsium-137 persists at levels not far below what is seen in average sewage. Measurements ${ }^{2}$ made of the cæsium-137 concentration in the local surface sea water early this year by us, gave an average of about $0 \cdot 1$ unc. per litre. This should be compared with the value of $0.4 \mu \mu c$. per litre representing the average concentration in the Hyperion sewage at the same period.

It is useful to compare average coneentrations in this manner, but it should be pointed out that even in spocimens taken from nearby points in the open sea the concentration may vary by more than 50 per cent. Smaller average concentrations were measured ${ }^{2,3}$ in local coastal waters than in waters far off this coast; and Yamagata ${ }^{7}$ has reported the average concentration for 1959 Japanese coastal water of $0.38 \mu \mu \mathrm{c}$. per litre, or essentially what has been obsorved in Hyperion sewage.

Even the peak concentrations obsorved at this plant should cause no alarm. From plant characteristies, it may be estimated that the largest peak in Fig. I corresponds to a batch input of about 0.4 curie. However, the sewage travels on the average 30 miles to the plant and is not likely to pass through in much less than one day, and the 250 million gallons of water put through in one day would diluto this to an average concentration of only $3.7 \times 10^{-7}$ uc. $/ \mathrm{ml}$. This falls far below the value of $2 \times 10^{-5}$ $\mu c . / \mathrm{ml}$. now accepted as maximum permissible concentration for this particular isotope in water that is to be drunk continually by humans.

From these investigations something has been leamed eoncerning the behaviour of radiocæsium in a large modern sewage disposal plant, and useful conclusions can be drawn concerning the probsble influence on the downstream environment. It can be seen, for example, that the original objective of following the local dispersal of sewage by the ocean can be attained only if the most sensitive and refined methods are applied. It appears, too, that suitable monitoring of the gammo-ray activities in sowage systems might provide additional safeguards to the public against misuse of the radioactive materials that are becoming more and more common in research, medicine and in industry.

This work was supported by the United States Atomic Energy Commission under Contract No. $A T(11-1)-34$, sponsored by Dr. A. B. Joseph, and made use of facilities supplied by the United States Office of Naval Research under Contract Nonr-233(34), sponsored by Dr. William Thaler. We are particularly indebted to Prof. J. E. McKee of the California Institute of Technology for consultations, and wish to acknowledgo the co-operation of the profossional staff of the Bureau of Sanitation of the City of Los Angeles, especially N. B. Hume, R. D. Bargman, J. M. Parkes, G. A. Betz, W. F. Garber, and C. G. Gunnerson. We are grateful to Dr. E. C. Anderson for supplying before publication the values for dried milk seen in Fig. 1 .

${ }^{1}$ Folsom, T. R., and Cramer, R. A., Scripps Inst. Interim Teeh. Rep. (1958). "Folsom, T. R., Mohanrao, G. J., and Winchell, Perrin, Nature, 187,
$480(1960)$.

${ }^{3}$ Mohanrao, G. J., and Folsom, T. R. (submitted to Anal. Chem., 1960).

${ }^{4}$ Anderson, E. C., Schuch, R. R., Fisher, W. R., and Langham, Wright, Science, 125, 1273 (1957).

${ }^{5}$ Langham. Wright. and Anderson, E. C., Hearings, Joint Committee on Atomic Energy, 2, 1067 (1959).

${ }^{6}$ MeNeill, K. G., and Green, R. M., Canad. J. Phys., 37, 528 (1950).

Yamagata, N., Nature, 184, 113 (1960).

\title{
OBITUARIES
}

\section{Dr. J. M. Cowan, C.B.E.}

Wiтh the sudden death of Dr. John Macqueen Cowan on the evening of October 26, after a very happy day with his friends on the Gardens Committee of the National Trust for Scotland, Scotland lost one of her most distinguished horticulturists.

A son of the manse, he was born in Banchory, Kincardineshire, in 1892, received his early education at Gordon's College, Abordeon, attended the University of Edinburgh, taking the arts and science degrees with honours in botany, became an undergraduate at Oxford, reading honours in botany with Prof. Vines and Dr. Church and forestry with Sir William Schlich, before being appointed to the Indian Forest Service. At Oxford he met Adeline May Organe, who took an honours degroe in botany, whom he married and who at all times was the source of the greatest possible encouragernent to him; in fact, she was co-author of ono of his earliest publications, "The Trees of Northern Bengal" (1929). In India he followed the example of some of his distinguished predecessors in tho Forost Sorvico, such as Brandis, Lace and Gamble, pursuing his botanical investigations as well as proving himself a forest officer of outstanding merit. It was not surprising, thoroforo, that from that Service he was chosen to officiate as superintendent of the Royal Botanie Gardens, Calcutta, the chief botanical post in the Indian Empire.

Retiring from India in 1928 and after undertaking, with Dr. C. D. Darlington, a botanical expedition to Iraq and Persia, on behalf of Kow and the John Innos Horticultural Institution, Cowan returned to Scotland in 1930 as assistant to Sir William Wright Smith, the regius keeper of the Royal Botanic Garden, Edinburgh. Soon he was deeply engrossed in the taxonomy of the genus Rhododendron, the gonus which had fired the enthusiasm not only of his immediato chief but also of tho professor who had lectured to him as an Edinburgh student, Sir Isaac Bayley Balfour. On the taxonomy of this complex genus ho publishod widoly, often in collaboration with his Edinburgh colleagues; he published, too, on the genera Cyananthus, Roscoea, Wendlandia and othors, as well as on the history of the Royal Botanic Carden. At all times he took a keen interest in the welfare of the hortioultural students in the Garden, and if at times the students were not altogether approving of some of his teaching methods, thoy were always appreciative of the generous hospitality of the Cowan household.

Late in the 1940's Cowan became deeply interestod in the retivities of the National Trust for Scotland, 
and especially interested in the two great Scottish gardens the Trust took over-Crathes in Kincardineshire and Inverewe in Ross and Cromarty. He gave great prestige to the Trust when, under the Trust's auspices, he inaugurated the early 'Garden Cruises', a unique and previously unused method of transport which has enabled people from all parts of the world to visit famous, and sometimes somewhat inaccessible, gardens in great comfort.

Happy and industrious though he had been in India, and undoubtedly was in Edinburgh, he frankly admitted that not until he retired from Edinburgh in 1954 and accepted the post of gardens adviser to the National Trust for Scotland, with his headquarters at Inverewe House on the incredibly lovely and rocky peninsula at Poolewe, did complete contentment and satisfaction come to him; and naturally so, when through his great energy and drive he saw the number of visitors to the Garden steadily increase from a few hundreds in 1954 to 47,000 in 1960 .

Cowan's services to horticulture were acknowledged by the Royal Horticultural Society by the award of the Veitch Memorial Medal in 1951 and by the Victoria Medal of Honour in 1955. He was made C.B.E. in 1952. Mrs. Cowan and a son and daughter survive him.

H. R. Fletcher

\section{Prof. Yehuda Hirshberg}

Prof. Yeruda Hirshbera, head of the Laboratory of Photochemistry and Spectroscopy in the Weizmann Institute in Rehovoth, Israel, died on September 20. Prof. Hirshberg was born in 1903, went to Israel as a pioneer in 1923 and joined a Kibbuz. After a strenuous year he fell ill with malaria, and was compelled to move to Jerusalem. There he worked as a labourer and at the same time enrolled as one of the first students in the pre-faculty of sciences of the Hebrew University. $\mathrm{He}$ studied chemistry under Prof. A. Fodor, and graduated in 1928 (unofficially, since the Hebrew University was not yet recognized at the time). Being an outstanding student, he was given a study grant which enabled him to go to Brussels, where he continued his studies towards the degree of doctor of science under two distinguished teachers-Victor Henry and Jaques Errera. Despite the difficulties of a new language and environment, he completed his studies with great distinction, and was appointed an assistant. His first independent research paper was published in 1932. A yoar later he made the acquaintance of Chaim Weizmann, who soon recognized the high qualities of the young scientist and invited him to serve as the physical chemist of the Daniel Sieff Research Institute which was planned at the time. Thus began Hirshberg's life-long association with the Sieff and Weizmann Institutes. His scientific career can truly be called a fruitful one, as witnessed by nearly ninety research papers in various seientific journals. His well-known discovery of 'photochromism' in 1950 and the investigation of this phenomenon and of the 'photochemical memory' led by him since then, won him world-wide recognition and international acclaim.

Despite his success, he never ceased to be a 'man of the people', being on friendly terms with every. body, irrespective of grade or standing. His personality was marked by boundless devotion to his work, willingness to help, and eagerness to make a friend of whomever he met, a goal which he achieved almost always, thanks to his rich Jewish humour and his good-heartedness.

His last years were marred by great suffering because of his many maladies. Nevertheless, he put up a stubborn fight against his disease and refused to give in. He was active in the laboratory and full of plans to his last day, and succumbed to a heart attack while still wearing his white laboratory coat.

His colleagues and collaborators will always remem. ber his high human qualities, his scientific ingenuity, and his infectious enthusiasm, and hope that the work being continued in his laboratory will serve as a living monument to him.

E. FISCHER

\section{Dr. Robert W. Lawson}

Robert William Lawson, who died in hospital on November 14 in his seventy-first year, was a lecturer in the Physics Department of the University of Sheffield for thirty-six years. He went from his native town of Gateshead to Armstrong College (now King's College), Newcastle upon Tyne, in 1908 and obtained a first-class degree with honours in physics. This was followed by two years research work in the College on the production of those high-frequency oscillations which later developed into radio-waves, but the study of which was then in its infancy. This brought him an award which onabled him to go to the Radium Institute in Vienna in early 1914. He was interned on the outbreak of war but generously released on parole, so that he could continue his researches into radioactivity at the Institute. He worked long hours under difficult conditions, on an inadequate diet, and published a number of papers, particularly on the rate of emission of alpha-particles from radium. The result he obtained in this investigation was verified by later workers and is accepted as the standard value. These papers earned him the award of the degree of doctor of science of his own University of Durham. He also became one of the first Fellows of the Institute of Physics when it was founded.

On his return to Britain in 1919, Lawson was appointed a lecturer in physics at Sheffield and remained there for the rest of his life, being made a senior lecturer on the establishment of this grade. The privations he suffered in Vienna had an adverse effect on his health, and it was some time before this was sufficiently restored for him to resume experimental research. The work of teaching the influx of ex-Service students could not be deferred, however, and at once he entered on a life of service to the Physics Department. He was a lucid lecturer and it was his delight to give experimental demonstrations of his talks whenever possible. In the early nineteentwenties he was placed in charge of the laboratories in which both the special and general degree students worked. Thus he had a large share in training the many Sheffield physicista who have attained distinction. He devised many ingenious experiments for them, some of which were shown at the open meetings of the Sheffield Physical Society which he organized between the two World Wars. He had a wide circle of friends among Continental physicists, and this, together with his proficiency in German, led to the publication of several translations of important books. Probably the most noteworthy of these was "Relativity", by Einstein, the first simple exposition of the theory which has affected science 